\title{
FROM THE EARLY DAYS OF UNMANNED AERIAL VEHICLES (UAVS) TO THEIR INTEGRATION INTO WIRELESS NETWORKS
}

\author{
Zoran M. Miličevića Zoran S. Bojkovićb \\ a Serbian Armed Forces, General Staff, Telecommunications and \\ Information Technology Directorate (J-6), \\ Belgrade, Republic of Serbia, \\ e-mail: zoranmilicko@gmail.com, corresponding author, \\ ORCID iD: Dhttps://orcid.org/0000-0003-3512-4188 \\ b University of Belgrade, Belgrade, Republic of Serbia, \\ e-mail: z.bojkovic@yahoo.com, \\ ORCID iD: (i)https://orcid.org/0000-0003-1323-0115
}

DOI: 10.5937/vojtehg69-33571; https://doi.org/10.5937/vojtehg69-33571

FIELD: Telecommunications

ARTICLE TYPE: Review paper

Abstract:

Introduction/purpose: This paper provides an overview of Unmanned Aerial Vehicles (UAVs) from their early days to their integration into modern wireless networks.

Methods: It analyzes, synthesizes and compares the UAVs development technologies throughout their history with significant aspects of their integration in wireless communication networks.

Results: Important aspects of wireless communications as one of the key technologies for UAVs are presented. Next, energy efficiency as a research path for UAVs is considered. The paper also emphasizes the present state in this area as well as what the future of UAVs in communications will be.

Conclusion: UAVs are important not only for widespread military usage in various combat operations and warfare environment, but also for other purposes such as their integration in $5 G$ networks.

Key words: unmanned aerial vehicles (UAVs), drone swarm, Military Internet of Things (MloT).

\section{Introduction}

Unmanned aerial vehicles (UAVs), also known as drones, are aircraft piloted by remote control without human on board. Embedded 
computer programs are included, too. A drone tends to be defined in different ways. Two of them are as follows:

- "An unmanned aircraft or ship guided by remote control or board computers" (Meriam Webster's America's most-trusted online dictionary for English word definitions and meanings).

- "A drone in technological terms is an unmanned aircraft. Essentially, a drone is a flying robot that can be remotely controlled or fly autonomously through software controlled plans in their embedded systems, working in conjunction with on board sensors and GPS" (Internet of Things Agenda).

UAVs have enormous potential in enabling new applications in various areas ranging from aerial inspection, photography, precision agriculture, traffic control, search, package delivery, telecommunications, medicine, surveillance, etc. Emerging technologies can benefit from significant potential of UAVs equipped with cameras, sensors and GPS receivers in delivery Internet of Things (IOT) services from great heats, creating an airborne domain of the loT. Also, the Military Internet of Things (MloT) represents a class of the Internet of Things for combat operations and warfare. On the other hand, the military loT could be treated as an internal network with a group of distributed smart objects such as military vehicles, weapons, soldiers, equipment, etc. interconnected with the existing military infrastructure, command and control systems. However, there are many issues to be resolved before the effective use of UAVs can be made including security, privacy, and management.

\section{Background}

In should be noted that the earliest military drones appeared in the mid-1850s. The conception dates back to 1849 during the war (see Table I) between Austria and Venice. Unmanned balloons with explosives were used. The Austrian forces launched around 200 incendiary balloons with $11 \mathrm{~kg}$ to $14 \mathrm{~kg}$ bombs each. It is interesting to note that only one bomb found its mark, while most of the balloons were blown away due to a change in wind direction. From the point of view of military technology, the use of balloons does not meet the current definitions of drones. 
Table 1 - UAVs background

Таблица 1 - Сведения о беспилотных летательных аппаратах Табела 1 - Историјат беспилотних летелица

\begin{tabular}{|c|c|c|c|c|c|}
\hline No. & NAME & YEAR & REASON & DESIGNED BY & CHARACTERISTICS \\
\hline 1. & $\begin{array}{l}\text { Earliest } \\
\text { military } \\
\text { drones }\end{array}$ & $\begin{array}{l}1845- \\
1850\end{array}$ & $\begin{array}{l}\text { The war } \\
\text { between } \\
\text { Austria and } \\
\text { Venice }\end{array}$ & Austrian forces & $\begin{array}{l}\text { Unmanned balloons } \\
\text { equipped with } \\
\text { explosive }\end{array}$ \\
\hline 2. & Gyroplane & 1905 & $\begin{array}{l}\text { Work on } \\
\text { the } \\
\text { gyroplane }\end{array}$ & $\begin{array}{l}\text { Louis Breguet } \\
\text { with his brother } \\
\text { Jacques and } \\
\text { under the } \\
\text { guidance of } \\
\text { Charles Richet }\end{array}$ & $\begin{array}{l}\text { Forerunner of the } \\
\text { helicopter with flexible } \\
\text { wings }\end{array}$ \\
\hline 3. & $\begin{array}{l}\text { Quadcopter } \\
\text { configuration } \\
\text { of drones }\end{array}$ & 1907 & $\begin{array}{l}\text { All UAVs } \\
\text { are drones }\end{array}$ & $\begin{array}{l}\text { Louis Breguet } \\
\text { with his brother } \\
\text { Jacques and } \\
\text { under the } \\
\text { guidance of } \\
\text { Charles Richet }\end{array}$ & $\begin{array}{l}\text { Rotary-using aircraft } \\
\text { that has } 4 \text { main } \\
\text { rotors/propellers } \\
\text { controlled or auto } \\
\text { guided }\end{array}$ \\
\hline 4. & $\begin{array}{l}\text { Drone by } \\
\text { Ruston } \\
\text { Proctor }\end{array}$ & 1916 & $\begin{array}{l}\text { Aerial } \\
\text { target }\end{array}$ & Ruston Proctor & $\begin{array}{l}\text { Used against } \\
\text { zeppelins }\end{array}$ \\
\hline 5. & $\begin{array}{l}\text { Archibald } \\
\text { Low system }\end{array}$ & 1917 & $\begin{array}{l}\text { Radio } \\
\text { guidance } \\
\text { system }\end{array}$ & Archibald Low & First wireless rocket \\
\hline 6. & $\begin{array}{l}\text { Kettering } \\
\text { Bug }\end{array}$ & 1917 & $\begin{array}{l}\text { To } \\
\text { represent } \\
\text { "aerial } \\
\text { torpedo" }\end{array}$ & U.S. Army & $\begin{array}{l}\text { Gyroscopic control } \\
\text { intended to represent } \\
\text { "aerial torpedo" }\end{array}$ \\
\hline 7. & OQ-2 & 1930 & $\begin{array}{l}\text { Radio } \\
\text { control } \\
\text { system } \\
\end{array}$ & Walter Righter & $\begin{array}{l}\text { Small radio-controlled } \\
\text { aircraft model }\end{array}$ \\
\hline 8. & Queen bee & 1935 & $\begin{array}{l}\text { Radio } \\
\text { control }\end{array}$ & $\begin{array}{l}\text { British radio } \\
\text { control }\end{array}$ & $\begin{array}{l}\text { Radio-controlled target } \\
\text { drone }\end{array}$ \\
\hline 9. & $\begin{array}{l}\text { ID-2D-1 } \\
\text { Curtiss TD- } \\
\text { 2D-1 }\end{array}$ & 1942 & $\begin{array}{l}\text { Reverse- } \\
\text { engineered }\end{array}$ & Americans & $\begin{array}{l}\text { Pulse jet-powered } \\
\text { unmanned aerial } \\
\text { drones }\end{array}$ \\
\hline 10. & $\begin{array}{l}\text { A V-1 } \\
\text { 'Doodlebug' }\end{array}$ & 1944 & $\begin{array}{l}\text { Flying } \\
\text { bomb }\end{array}$ & German army & $\begin{array}{l}\text { simple autopilot to } \\
\text { control altitude and air } \\
\text { speed }\end{array}$ \\
\hline 11. & $\begin{array}{l}\text { SR-71 } \\
\text { Blackbird }\end{array}$ & 1950 & Spy plane & $\begin{array}{l}\text { Mach strategic } \\
\text { reconnaissance } \\
\text { aircraft developed } \\
\text { and manufactured } \\
\text { by Lockheed } \\
\text { Martin Corporat. }\end{array}$ & $\begin{array}{l}\text { Long-range, high } \\
\text { altitude }\end{array}$ \\
\hline
\end{tabular}




\begin{tabular}{|c|c|c|c|c|c|}
\hline No. & NAME & YEAR & REASON & DESIGNED BY & CHARACTERISTICS \\
\hline 12. & Ryan 147BS & 1950 & $\begin{array}{l}\text { Jet- } \\
\text { powered } \\
\text { drone }\end{array}$ & $\begin{array}{l}\text { Ryen } \\
\text { Aeronautical }\end{array}$ & $\begin{array}{l}\text { To recover any } \\
\text { information gathered }\end{array}$ \\
\hline 13. & HAL SOL & 1980 & $\begin{array}{l}\text { Alternative } \\
\text { power } \\
\text { source for } \\
\text { drones } \\
\end{array}$ & $\begin{array}{l}\text { Sponsored by the } \\
\text { CIA }\end{array}$ & Solar-powered aircraft \\
\hline 14. & $\begin{array}{l}\text { RQ2 } \\
\text { Pioneer }\end{array}$ & 1986 & $\begin{array}{l}\text { Building an } \\
\text { inexpensive } \\
\text { drone for } \\
\text { fast } \\
\text { operations }\end{array}$ & $\begin{array}{l}\text { A join project by } \\
\text { the U.S. and } \\
\text { Israel }\end{array}$ & $\begin{array}{l}\text { Medium-sized } \\
\text { reconnaissance } \\
\text { aircraft }\end{array}$ \\
\hline 15. & $\begin{array}{l}\text { Versions of } \\
\text { UAVs }\end{array}$ & 1990 & $\begin{array}{l}\text { Mini and } \\
\text { macro }\end{array}$ & AeroVironment & $\begin{array}{l}\text { Mini and macro } \\
\text { Predator version }\end{array}$ \\
\hline 16. & Predator & 2000 & $\begin{array}{l}\text { To lunch } \\
\text { missiles }\end{array}$ & General Atomics & $\begin{array}{l}\text { Mini and macro } \\
\text { versions of UAVs }\end{array}$ \\
\hline 17. & $\begin{array}{l}\text { Raven, } \\
\text { Wasp, Puma }\end{array}$ & $\begin{array}{l}\text { After } \\
2000\end{array}$ & $\begin{array}{l}\text { Small-sized } \\
\text { fixed-wing } \\
\text { drones }\end{array}$ & $\begin{array}{l}\text { AeroVironment } \\
\text { Inc. }\end{array}$ & $\begin{array}{l}\text { Fixed-wing } \\
\text { surveillance drones }\end{array}$ \\
\hline 18. & $\begin{array}{l}\text { Commercial } \\
\text { drone }\end{array}$ & 2006 & $\begin{array}{l}\text { First } \\
\text { commercial } \\
\text { drone } \\
\text { permit was } \\
\text { issued }\end{array}$ & FAA & $\begin{array}{l}\text { Pivotal year of the } \\
\text { history of drones, with } \\
\text { consumer application } \\
\text { slow to start and with } \\
\text { a small number of } \\
\text { people applying for } \\
\text { permits in the first few } \\
\text { years }\end{array}$ \\
\hline 19. & $\begin{array}{l}\text { Drone- } \\
\text { innovation }\end{array}$ & $\begin{array}{l}2006- \\
2015\end{array}$ & $\begin{array}{l}\text { Commercial } \\
\text { interest }\end{array}$ & $\begin{array}{l}\text { A lot of different } \\
\text { manufacturers }\end{array}$ & As delivery vehicles \\
\hline 20. & $\begin{array}{l}\text { Operation } \\
\text { rules of } \\
\text { small UASs }\end{array}$ & 2016 & $\begin{array}{l}\text { Operational } \\
\text { rules }\end{array}$ & FAA & $\begin{array}{l}\text { Use of small devices } \\
\text { with aircraft weight } \\
\text { less than } 25 \mathrm{~kg} \text { (small } \\
\text { unmanned aerial } \\
\text { system UASs) }\end{array}$ \\
\hline 21. & $\begin{array}{l}\text { National } \\
\text { program }\end{array}$ & 2017 & $\begin{array}{l}\text { National } \\
\text { program } \\
\text { "Drone } \\
\text { integration } \\
\text { pilot } \\
\text { program" }\end{array}$ & FAA & $\begin{array}{l}\text { To explore the } \\
\text { expanded use of } \\
\text { drones including } \\
\text { beyond visual line of } \\
\text { sight flight, night time } \\
\text { operations and fight } \\
\text { over people }\end{array}$ \\
\hline
\end{tabular}

In 1907, an early development of this technology appeared, called the quadcopter configuration. That year, Louis Breguet (Figure 1) and his brother together with the help of French physiologist Professor Charles 
Richet (Figure 2), developed a gyroplane, the forerunner of the helicopter. It should be noted that in 1905 Louis Breguet with brother Jacques and under the guidance of Charles Richet began work on a gyroplane, the forerunner of the helicopter.

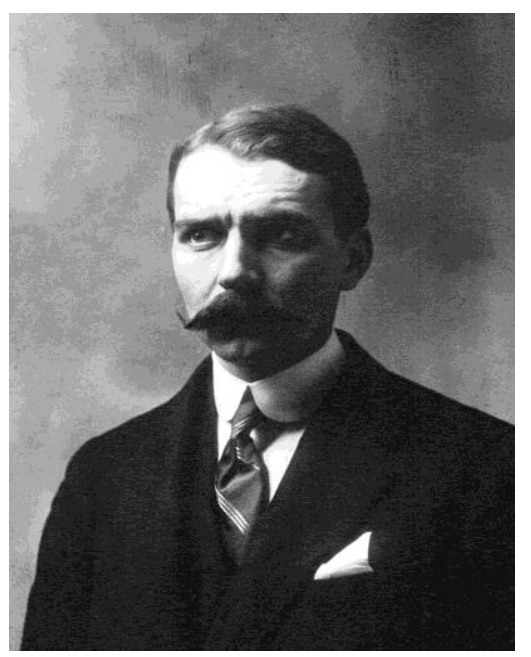

Figure 1- Louis Charles Breguet (Wikimedia Commons, 2021a) Puc. 1 - Луи Шарль Бреге (Wikimedia Commons, 2021a) Слика 1 - Луи Шарл Бреге (Wikimedia Commons, 2021a)
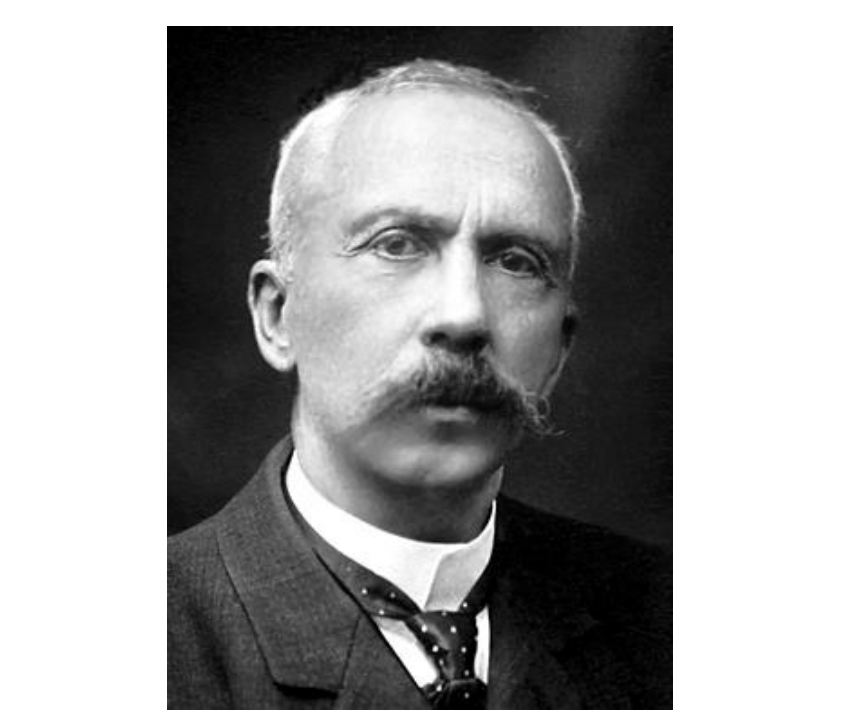

Figure 2 - Charles Robert Richet (Wikimedia Commons, 2021b) Puc. 2 - Шарль Pоберm Puше (Wikimedia Commons, 2021b) Слика 2 - Шарл Роберm Puшe (Wikimedia Commons, 2021b) 
British engineer Archibald Low (Figure 3) developed a radio guidance system in 1916 and during Word War I, he used it in the radiocontrolled plane called the Ruston Proctor Aerial Target.

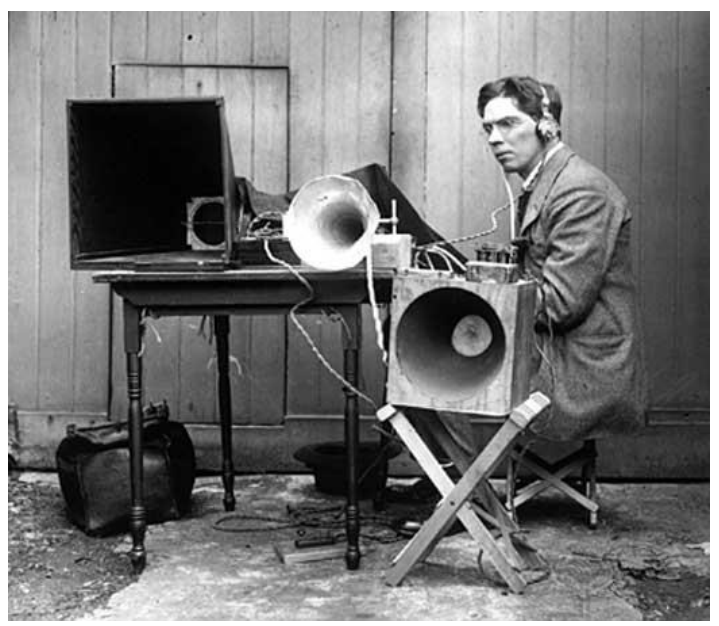

Figure 3 - Archibald Montgomery Low (A. M. Low) (Wikipedia, 2021)

Puc. 3 - Арчибальд Монтгомери Лоу (A. М. Лоу) (Wikipedia, 2021)

Слика 3 - Арчибалд Монгомери Лоу (A. M. Лоу) (Wikipedia, 2021)

In 1917, Archibald Low, who was named the father of radio guidance systems, invented the first wireless rocket together with his research group. After this, the U.S. Army built the Kettering Bug with gyroscopic controls and intended to present an "aerial torpedo" (Figure 4).

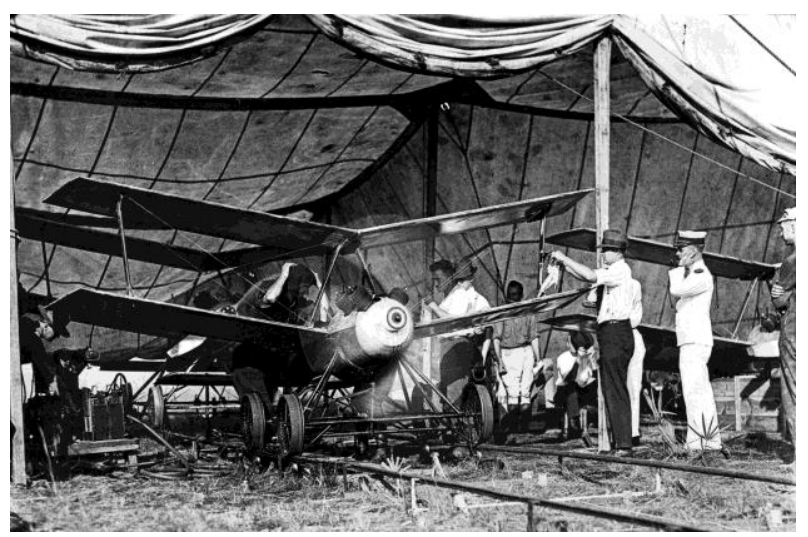

Figure 4 - Photograph of the Kettering Bug prototype (Wikimedia Commons, 2021c) Puc. 4 - Фотография прототипа «Жука» Keтmеринга (Wikimedia Commons, 2021c)

Слика 4 - Фотографрија прототипа „Кетеринг Буг” (Wikimedia Commons, 2021c) 
In the 1930s, the OQ-2 was a small radio-controlled aircraft model designed by Walter Righter. UAV technological developments continued. The U.S. Navy began experimenting with radio-controlled aircraft. The British developed "Queen Bee" which is a radio-controlled target drone also believed to have led to "drone" for radio-controlled unmanned aircraft. The first war-produced UAV product in the U.S. was a remotecontrolled model airplane developed by British actor Reginald Denny and Walter Righter in the 1930s. Edward M. Sorensen was an inventor of a radio-controlled aircraft that could fly out of sight. He patented a ground terminal to track the movements of the airplane. The significance of this event should be noted because the early aircraft could only operate within the visual sight of the controlling pilot. The "Doodlebug" of the German army was the most notable event of the Second World War with regards to drones. This aircraft was the world's first missile. Its guidance system used a simple autopilot to control altitude and air speed.

The next big step in drone technology occurred during Vietnam War which saw the first widespread deployment and use of drones as dedicated UAVs.

In the late 1950s, the U.S. spy plane, the manned SR-71 Blackbird, was still in development, while spy satellites were also not ready for deployment. Specialized UAVs were needed to safely gather information in control areas. SR-71 Blackbird was a long-range, high altitude strategic reconnaissance aircraft developed and manufactured by Lockheed Martin Corporation. (Figure 5).

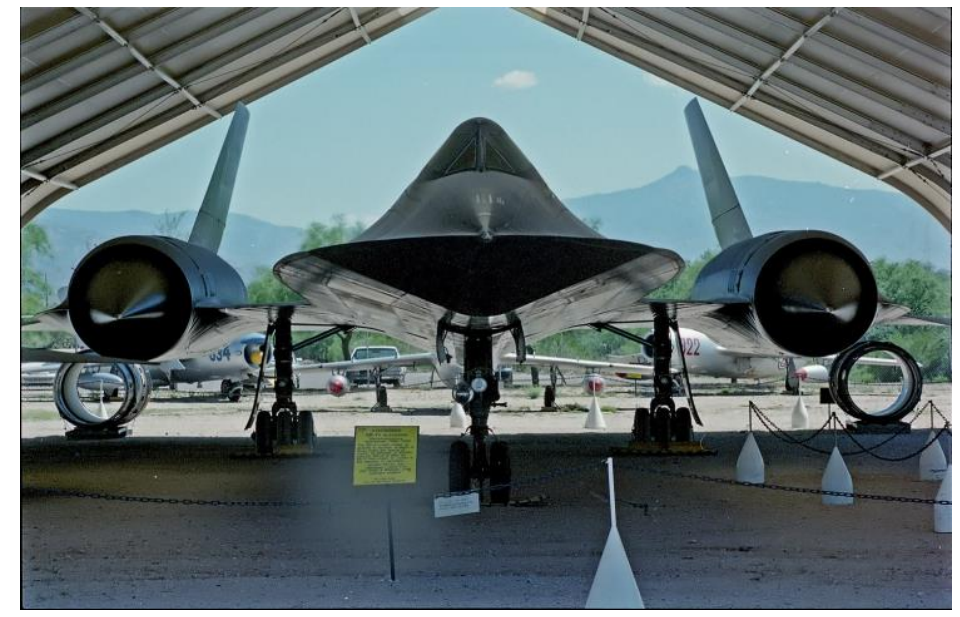

Figure 5 - Lockheed Sr-71 (Wikimedia Commons, 2021d)

Puc. 5 - Lockheed Sr-71 (Wikimedia Commons, 2021d)

Слика 5 - Локид Cp-71 (Wikimedia Commons, 2021d) 
Some models did exist, like the Ryan 147BS, but they were parachuted to the ground to gather information. Ryan's Model 147BS is a jet-powered drone, unmanned aerial vehicle produced and developed by Ryan Aeronautical from the earlier Ryan Fireface target drone series. The need for drones exists in many countries who explore the use of UAVs for different applications. New drone models are becoming more and more sophisticated. As for design, they focus on improving the height at which the drones could safety operate. Thanks to transistor technology, radio-controlled components are minimized enough for serving to civilian customer purposes.

In 1980, the U.S. began the UAV Program with the aim of building an inexpensive drone for fast operations. The development of the RQ2 Pioneer was the result of a joint project of the U.S. and Israel in 1986. It was a medium-sized reconnaissance aircraft (Figure 6).

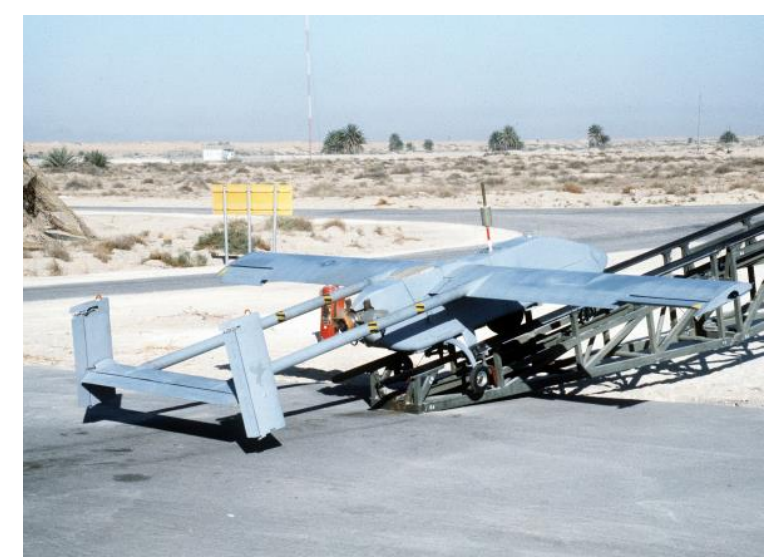

Figure 6-RQ-2 Pioneer on launch rail 1 (Wikimedia Commons, 2021e)

Puc. 6 - RQ-2 «Пионер» на пусковой установке 1 (Wikimedia Commons, 2021e)

Слика 6-Пионир RQ-2 на стратној шини 1 (Wikimedia Commons, 2021e)

During this period, drone developers were focused on alternative power services for drones, where the main service was solar power. This led to some interesting solar-powered drones called AERO-Vironment HAL SOL. The High Amplitude (AAL SOL) Solar-powered unmanned aircraft was sponsored by the CIA in 1980s as the first solar-powered aircraft. Mini and micro versions of UAVs were introduced in 1990, while the Predator drone was introduced in 2000.

A number of small-sized, fixed-wing surveillance drones such as Raven, Wasp and Puma, developed by AeroVironment Inc., were 
developed after 2000. Raven, for example, is used in many countries, with tens of thousands of units deployed (Figure 7).

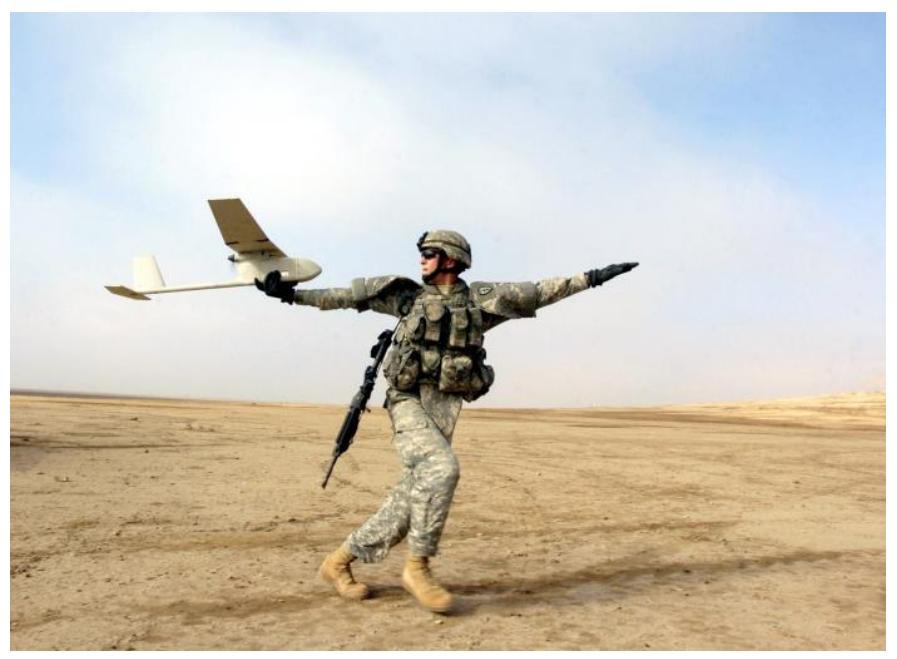

Figure 7-RQ-11 Raven (Wikimedia Commons, 2021f)

Puc. 7-RQ-11 Ворон (Wikimedia Commons, 2021f)

Слика 7-Гавран RQ-11 (Wikimedia Commons, 2021f)

Another year in the history of drones was 2006 when the first commercial drone permit was issued. However, the number of people applying for permits in the first year was small. The huge expansion in drone innovation was evident in the last 10 years in commercial interest, too. For example, in the early 2010s, drones were used not only as military vehicles, but also as delivery vehicles. Around 1000 commercial drone permits were issued in 2015 and a demand for drones has continued to grow exponentially. The year 2010 might just be the socalled "golden age of drones". The number tripled one year later. As a result of merging radio-controlled aircraft and smartphone technology, equipping drones with cameras is a new commonplace in commercial photography and videography. In 2013, a group of researchers examined emerging fields challenging for military: the buildup of ice on drones and other unmanned aerial vehicles. UAVs were not outfitted with protection to eliminate ice buildup. The prototype of the system was tested in 2015. Since then, the technology has been tested regularly in wind tunnels and on board during UAV flights. In 2016, the U.S. Federal Aviation Administration (FAA) released the operational rules for routine civilian use of small UAVs with aircraft weight less than $25 \mathrm{~kg}$. In November 2017, the FAA launched the national program "Drone Integration Pilot 
Program" to explore the expended use of drones including beyond visual line-of-sight flying, night-time operations, and flights above people. Drones are becoming very attractive not only because of their fast deployment and low cost, but also because of their ability to hover (Hayat et al, 2016, pp.2624-2661). The size of air drone-cells can be adjusted by changing their altitude, transmission power antenna directivity, and other parameters, providing more adaptability to unstable traffic loads and variable user distributions (Ferranti et al, 2018, pp.1-12). Supporting aerial users with cellular networks goes back to the 2000s with the use of the global system for mobile communication (GSM) 2G (Goddemeier et al, 2010, pp.1760-1765). Later, UAV flight tests were conducted over 3G Universal Mobile Telecommunication System (UMTS) networks. The 3G UMTS network could provide a possible solution for no safety-critical communications for aerial users with moderate speed and altitude of 1220m (Gonzalez et al, 2011. pp.240-248).

Next, 4G Long Term Evolution (LTE) is promising to support aerial users and UAV applications. LTE achieved the best performance in terms of latency and jitter with round trip time of $127 \mathrm{~ms}$ and a standard deviation of $48 \mathrm{~ms}$ for the worst case scenario (Afonso et al, 2016, pp.411). Such results demonstrated the feasibility of UAV operations over the LTE network with a low altitude of up to $100 \mathrm{~m}$.

The Third Generation Partnership Project (3GPP) investigation has proved that the existing LTE networks support the UAV deployment with low density and low altitude without need of major changes. As the number of UAVs grows, it is of importance to develop new technologies to enable cellular-connected UAVs in term of 3-D aerial coverage and effective air-ground interference migration.

In 2017, the technology called D.ICE was commercialized by the university in Trondheim. With UAVs, just as with larger aircraft, the accumulation of ice during flight on wings, propellers, and tails can make it hazardous to fly and even cause them to crash. Frozen water on wings increases their weight thus reducing lift and can cause an aircraft to stall. Ice on the propeller can increase drag. Sensors can lock up interfering with the autopilot's ability to gauge speed and altitude.

Icing on UAVs is a relatively new field of research with "unknown parameters". The electro thermal panel can be embedded in UAVs during the manufacturing process or attached to the existing wings. D.ICE uses two algorithms for icing detection. One is a thermal response from the heating zones; the other involves an aerodynamic approach in which the system estimates relevant parameters such as lift and drug and infers if they have degraded due to icing. 


\section{Basic requirements}

Wireless communication is one of the technologies for UAVs. The reason is very simple. On the one hand, UAVs need to exchange information with a remote pilot, nearby aerial vehicles and air traffic controllers in order to provide the safe, reliable, and efficient flight operation. The general name for it is Controlled Non-Payload Communication (CNPC) (ITU, 2009). On the other hand, UAVs have to transmit and/or receive mission related data (areal image, high speed video, UAV operators, end users, ground gateway). This is payload communication.

There are three CNPC types required for ensuring safe UAV operations communication:

- Communication for UAV Command and Control,

- Communication for Air Traffic Control, and

- Communication Supporting "Sense and Avoid".

The communication requirements specified by the Third Generation Partnership Project are shown in Table 2.

CNPC is of low data rate, for example in the order of $60-100 \mathrm{~kb} / \mathrm{s}$ for both downlink (DL) and uplink (UP) directions. On the other hand, reliability of less than $10^{-3}$ packet error rate and latency of less than 50 $\mathrm{ms}$ are required (Table 2). The communication requirements of CNPC links are similar for different types of UAVs due to their common safety those for payload data are highly application-dependent. Compared to CNPC, UAV payload communication is characterized by much higher data requirements.

Table 2 - UAV communications requirements specified by 3GPP (3GPP, 2017) Таблица 2 - Требования к системе связи беспилотных летательных аппаратов (БПЛА), предписанные ЗGPP (ЗGPP, 2017)

Табела 2 - Захтеви за комуникацију беспилотних летелица наведени у $3 G P P$ (3GPP, 2017)

\begin{tabular}{||l|l|l|l|l|}
\hline & $\begin{array}{l}\text { DATA } \\
\text { TYPE }\end{array}$ & $\begin{array}{l}\text { DATA } \\
\text { RATE }\end{array}$ & RELIABLITY & LATENCY \\
\hline $\begin{array}{l}\text { UL (GROUND } \\
\text { STATION TO } \\
\text { UAVs) }\end{array}$ & $\begin{array}{l}\text { Command } \\
\text { and control }\end{array}$ & $\begin{array}{l}60-100 \\
\mathrm{kbs}\end{array}$ & $\begin{array}{l}10^{-3} \text { packet } \\
\text { error rate }\end{array}$ & $50 \mathrm{~ms}$ \\
\hline $\begin{array}{l}\text { DL (UAVs TO } \\
\text { GROUND } \\
\text { STATION) }\end{array}$ & $\begin{array}{l}\text { Command } \\
\text { and control }\end{array}$ & $\begin{array}{l}60-100 \\
\mathrm{kbs}\end{array}$ & $\begin{array}{l}10^{-3} \text { packet } \\
\text { error rate }\end{array}$ & - \\
\cline { 2 - 6 } & $\begin{array}{l}\text { Application } \\
\text { data }\end{array}$ & $\begin{array}{l}\text { Up to } 50 \\
\mathrm{kbs}\end{array}$ & - & $\begin{array}{l}\text { Similar to } \\
\text { terrestrial user }\end{array}$ \\
\hline
\end{tabular}


For example, to support the transport of a full high-definition (FHD) video from the UAV to the ground user, the transmission rate is about several $\mathrm{Mb} / \mathrm{s}$, while for a $4 \mathrm{~K}$ video, it is higher than $30 \mathrm{Mb} / \mathrm{s}$.

\section{Influence of wireless communications}

Wireless technology is necessary for providing seamless connectivity throughput with high reliability in the 3-D space when taking into consideration air-to-air and air-to-ground connections. The most important communication technologies are: direct line, satellite, ad hoc network, and cellular network. These communication technologies are used for military systems and applications in various combat operations, too. For example, applications for military uses involve: reconnaissance, armed attacks, targets for military training, etc.

A direct line is used between an UAV and its associated ground node over, for example, the unlicensed $2,4 \mathrm{GHz}$ band. It is direct point-topoint communication with a simple, low cost, limited range, low data rate, vulnerable to interference and non-scalable. The ground node can be a remote controller, a station etc. It is limited to LOS communication. In urban areas, communication can be easily blocked by trees or high buildings. As a result, this gives low reliability as well as low rate. The ground node needs to connect to a gateway for enabling the Internet access of the UAV. One such solution is insecure and vulnerable to interception and jamming. It should be noted that a solution with direct line communication cannot be a scalable solution for supporting large scale deployment in future applications.

Satellites serve to link data transmitted between widely separated UAVs and ground gateways. This is of importance for UAVs above the ocean and also in remote areas in the case when terrestrial network (WiFi or cellular) coverage is not of practical use. In addition, satellite signals are used for navigation and localization of UAVs. As for disadvantages, there are some of them. First of all, propagation loss and delay are significant because of long distances between satellites and low altitude UAVs/ground stations. Next, UAVs have stringent size, weight, and power constraints. Finally, high operational costs represent one kind of inconvenience for wider use.

Each device in a mobile ad hoc network (MANET) can move over time and its line conditions may change frequently with other devices. Two applications of MANET are vehicular ad hoc network (VANET) and flying ad hoc network (FANET) for supporting communications among 
high-mobility ground vehicles and UAVs in 2-D and 3-D networks, respectively (Bekmezci et al, 2013, pp.1254-1270).

FANET is unable to provide a scalable solution for serving massive UAVs deployed in a wide area. The platform realizes a reliable routing protocol over the mobile network with dynamic and intermittent link connectives among flying UAVs.

Today, there is a growing interest in leveraging the existing and future-generation cellular networks for enabling UAV-ground communication (Zeng et al, 2018, pp.120-127).

Both CRC and payload communication requirements for UAVs can be met regardless of the density of UAVs and their distances with the corresponding ground nodes. There are scenarios where cellular services are not available (remote areas, sea, desert, forest). In this case, direct links, satellites and FANET are used to support UAV communication beyond the terrestrial coverage of cellular network. Thus, it is proposed that future wireless networks have an integrated 3-D architecture with UAV-to-UAV, UAV-to-Satellite and UAV-to-ground communication. In such a hybrid network, each UAV is enabled with one or more technologies to exploit rich connectivity diversity.

Also, it is important to emphasize that wireless communications with UAVs involve several typical use cases: UAV-aided ubiquitous coverage, UAV-aided relaying, and UAV-aided information dissemination/data collection. In the first use case, UAVs provide seamless coverage within the serving area, which is suitable for fast service recovery after infrastructure failure, as well as base station offloading in the hotspot application scenario. Next, in the second use case, UAVs connect two or more distant users or user groups thus supporting military operations, e.g. between the frontline and the headquarters, as well as enable big data transfer between data centers. Finally, in the third use case, UAVs provide periodic sensing and information multicasting.

\section{Communication on physical layer}

Unmanned aerial vehicle-drone networks are applied in the case of unexpected and temporal events. Each drone has wireless transceivers to communicate with the ground user equipment (UE) and other drones. Drones consist of equipment for receiving, processing, and transmitting signals in order to complement pre-existing cellular systems. In that way, the communication infrastructure becomes reinforced. This case can be of importance from the emergency and safety point of view (Milicevic \& Bakmaz, 2020). 
Today, the key technologies are: multiple-input multiple-output (MIMO), millimeters wave (mmWave) communication, non-orthogonal multiple access (NOMA) transmission, and cognitive radio (CR).

MIMO is one of the most important technologies when dealing with UAV military communications, because of command and control messages which require low latency and high reliability for application data such as, for example, video streaming. The beam forming gain provided by massive MIMO depends on the accuracy of channel slot information for all served users at each ground base station.

\section{Energy efficiency as an active research field}

The need to deal with energy efficiency was driven by:

a) The need to reduce the operation cost and green gas emission and

b) The importance to use the battery for different types of devices.

Energy-efficient UAV communications were focused only on reducing communication-related energy consumption of either the ground nodes (Zhan et al, 2018, pp.328-331) or the UAV (Li et al, 2016, pp.1377-1386).

Taking into consideration the UAV's propulsion energy consumption, there are research interests on energy efficient UAV communications. This invokes design problems due to the new tradeoff between minimizing the UAV propulsion energy consumption versus maximizing the communication throughput.

\section{State-of-the-art UAVs}

For the energy efficient trajectory plan of a drone, it is very important to extend its service time. Due to the limited computing ability of a single drone, multiple drones are worth considering in order to simultaneously provide computing services, where the movement control, cooperation and the resource allocation of multiple drones require elaborate design.

Today, UAVs have an exponential growth due to significant technological advances enabling numerous applications ranging from package delivery, traffic control, and video streaming to disaster recovery. Non Terrestrial Networks (NTNs) using UAVs in terms of highaltitude platforms and usage constellations of Low Earth Orbit satellites is going to be realized to provide global Internet service among many others. 
UAVs have a variety of applications in areas such as public safety, IoT, caching edge computing and smart cities, as well as in man-made and natural disasters like fires, floods, and earthquakes, providing wireless services to remote and unconnected areas. UAVs also assist ground wireless networks such as D2D communications and mmWave communications. Other applications include their usage in small and power limited devices for healthcare and transportation as well as for high data rate and low latency required in virtual reality applications. Also, the applications of UAV user equipment (UE) in scenarios of surveillance, package delivery, transportation, and remote sensing are of importance.

Mobile devices have become a very significant component of military operations, especially taking into account operations at the tactical edge. This implies that important portions of communications and processing are executed on resource-constrained and bandwidth-limited platforms and networks. One of the most critical aspects in military operations is providing the right information to the right person at the right time. $\mathrm{A}$ factor that simplifies searching for stored images in the cloud is that they may be processed before enabling quick search. The decision of where to do the process depends on the state of the military system, energy requirements, the quality of information objectives, and on what has been requested. As for video processing, one of the main problems is labeling all stored images/videos as fast as possible. When videos have been filtered by time and place, there are two steps for labeling, i.e., prime extraction and detection.

\section{Future of UAV communications}

There are still many open issues related to the performing UAV communications in $5 \mathrm{G}$ systems. For example, in certain use cases, there can exist some dissipations and barriers between UAVs and ground stations. In UAV-enabled multi-user non-orthogonal multiple access (NOMA) systems, the optimal user clustering and user-pairing algorithms are underexplored fields.

It should be noted that successive interference cancellation (SIC) relies on the channel state information at both the receivers and the transmitters to determine the allocated power for each receiver and the decoding order. One of possible problems is to eliminate the interlayer interference caused by multiplexing in the power domain. Next, the communication distance between the UAV and the ground user equipment would vary constantly based on the real-time requirements. 
Finally, the SIC decoding order determined by the received signal strength varies with the drone's location.

To provide seamless communication service to ground users over a wide area, a swarm of UAVs constructs a multihop network. Such architecture has centralized coordination enabled by ground infrastructure with computing capabilities (Campion et al, 2018, pp.903908).

The drawback is a round-trip air-ground delay for UAV coordination. Also, the ground infrastructure is heavily loaded when the number of UAVs in a swarm becomes large. An alternative for a UAV swarm is UAV-to-UAV communication. Here the infrastructure, for example a cellular network, offers the back-bone connectivity between the aerial networks, between UAVs (Zeng et al, 2018, pp.120-127). Some common technical features can be provided, including moveable wireless devices, long communication distance between nodes, a sufficiently high data rate, minimized communication delay, and line of sight affected by weather conditions. Currently, 5G is being applied into commercial use. Drone swarms also play an important role in $5 \mathrm{G}$ networks (Figure 8).

They may have to deal with huge data flow with low latency. To meet this demand, some communication technologies are considered for UAV swarms such as millimeter-wave, NOMA and cognitive radio (CR) (Saleem et al, 2015, pp.15-31).

Many academic and standardization groups have proposed the incorporation of CR and UAV communication systems to increase the spectrum opportunities (Saleem et al, 2015, pp.15-31).

This concept constitutes a promising network architecture that allows the coexistence of UAVs with terrestrial mobile devices working in the same frequency band.

The flexible deployment and strong line of sight links of UAVs are expected to make them an important component of future $5 \mathrm{G}$ and beyond wireless networks towards the provision of ubiquitous connectivity at any time. Business spectrum sharing among the UAVs and the fixed network infrastructure and the introduction of aerial networks imply additional challenges that need to be addressed. In particular, the energy supplied to UAVs has been identified as one major issue in aerial networks, since apart from the possibility of communication interruption, the possibility of physical damage is also looming. To deal with this problem, the idea of strategically deployed charging stations in urban and rural areas has been recently proposed in the literature. As UAVs gain ground in mobile communications and the 
number of UAV operations is expected to increase, limited places in charging stations should be allocated efficiently.

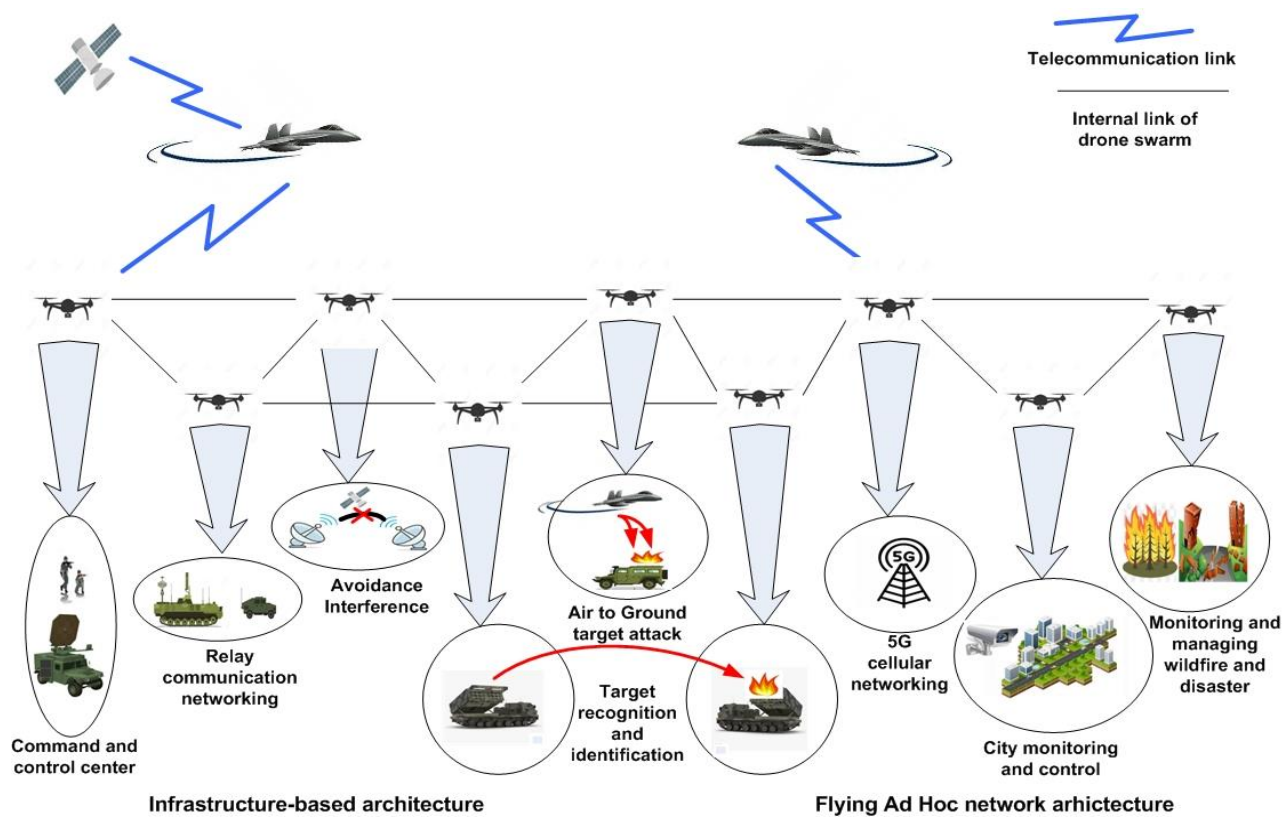

Figure 8-Drone swarm applications: possible scenario.

Puc. 8-Приложения для управления роем дронов: возможный сценарий Слика 8 - Могући сценарио примене ројева дронова

Finally, drone swarm control cooperative missions could be accomplished via control among different military combat and communication and control systems and applications intended for combat operations and warfare (Figure 8). Today militaries are moving ahead with attacks of swarming drones. For example, drones in swarms can be equipped for electronic warfare if needed, or swarms may consist of drones with guns, bombs, and missiles.

\section{Conclusion}

UAVs have a long tradition of more than one hundred years of development and exploitation. During this period of time, they have become one of the most important technology items which can be used both on its own and integrated in different systems and applications including cellular networks.

The usage of smartphones reduces the price of microcontrollers, accelerometers and camera sensors, which are devices convenient for 
use in fixed-wing aircraft. Advances allowed a drone with 4 or more rotors to be controlled by adjusting the speed of individual rotors. The growing use of unregulated UAVs has also accelerated privacy and physical safety. In that way, the future becomes highly promising. As for drones, it will occur across the segments such as: agriculture, construction and mining, insurance, media, and telecommunications. Drones are expected to become smaller and lighter with much longer battery life and flight time.

Also, there will be developments in improving drone optics. From the civilian point of view, improving flight time allows them to serve as delivery platforms, or to be used in emergency services and for data collections in a number of areas dangerous for humans, such as in power plants, fires, etc. Home security and crowd control are included too. Also, one important thing is miniaturization. As components become smaller and smaller, UAVs will be reduced in size; there will be, for example, microscopic drones in the future. Development in flight control algorithms, machine vision and onboard processing power will enable UAVs to make decisions themselves, rather than to rely on human input. In that way, the reaction time and speed will be improved. The flexible deployment along with strong line-of-sight links of UAVs are expected to make them an important component of 5G, and apart from being used in wireless networks, they are also to become components of various military systems towards the provision of ubiquitous any time connectivity (Li et al, 2019, pp.2241-2263).

Military networks are crucial in carrying out military actions. As images/videos are rich sources of information, the main challenge is to be in a position to issue a query over a large distributed set of devices to find concrete actions or objects of interest. The concrete MloT solution architecture depends on a specific military scenario and the area of application (Zieliński et al, 2021, pp.36-42).

Finally, energy supply was identified as one of major issues in aerial networks. In order to deal with this problem, the idea of deploying charging stations has been proposed by Z.W. Mekikis and Antonopoulos in 2019. However, UAV operators are expected to increase the limited space in charging stations. 


\section{References}

-3GPP. 2017. Technical Specification Group Radio Access Network: Study on enhanced LTE Support for Aerial Vehicle", document 3GPP TR 36.777 VIS.O.O. [online]. Available at: https://portal.3gpp.org/desktopmodules/Specifications/SpecificationDetails.aspx? specificationld=3231 [Accessed: 15 December 2020].

Afonso, L., Souto, N., Sebastiao, P., Ribeiro, M., Tavares, T. \& Marinheiro, R. 2016. Cellular for the skies: Exploiting mobile network infrastructure for low altitude air-to-ground communications. IEEE Aerospace and Electronic Systems Magazine, 31(8), pp.4-11. Available at: https://doi.org/10.1109/MAES.2016.150170.

Bekmezci, I., Sahingoz, O.K. \& Temel, Ş. 2013. Flying ad-hoc networks (FANETs): A survey. Ad Hoc Networks, 11(3), pp.1254-1270. Available at: https://doi.org/10.1016/j.adhoc.2012.12.004.

Campion, M., Ranganathan, P. \& Faruque, S. 2018. A Review and Future Directions of UAV Swarm Communication Architectures. In: IEEE International Conference on Electro/Information Technology (EIT), Rochester, MI, USA, pp.903-908, May 3-5. Available at: https://doi.org/10.1109/EIT.2018.8500274.

Ferranti, L., Cuomo, F., Colonnese, S. \& Melodia, T. 2018. Drone Cellular Networks: Enhancing the Quality Of Experience of video streaming applications. Ad Hoc Networks, 78, pp.1-12. Available at: https://doi.org/10.1016/j.adhoc.2018.05.003.

Goddemeier, N., Daniel, K. \& Wietfeld, C. 2010. Coverage evaluation of wireless networks for unmanned aerial systems. In: 2010 IEEE Globecom Workshops Conference, Miami, FL, USA, pp.1760-1765, December 6-10. Available at: https://doi.org/10.1109/GLOCOMW.2010.5700244.

Gonzalez, F., Walker, R., Rutherford, N. \& Turner, C. 2011. Assessment of the suitability of public mobile data networks for aircraft telemetry and control purposes. Progress in Aerospace Sciences, 47(3), pp.240-248. Available at: https://doi.org/10.1016/j.paerosci.2010.08.001.

Hayat, S., Yanmaz, E. \& Muzaffar, R. 2016. Survey on unmanned aerial vehicle networks for civil applications: A communications viewpoint. IEEE Communications Surveys \& Tutorials, 18(4), pp.2624-2661. Available at: https://doi.org/10.1109/COMST.2016.2560343.

-ITU (International Telecommunication Union). 2009. Characteristics of Unmanned Aircraft Systems and Spectrum Requirements to Support their Safe Operation in Non-Segregated Airspace, Report M.2171 [online]. Available at: https://www.itu.int/pub/R-REP-M.2171/en [Accessed: 15 December 2020].

Li, B., Fei, Z. \& Zhang, Y. 2019. UAV communications for $5 \mathrm{G}$ and beyond: Recent advances and future trends. IEEE Internet of Things Journal, 6(2), pp.2241-2263. Available at: https://doi.org/10.1109/JIOT.2018.2887086.

Li, K., Ni, W., Wang, X., Liu, R.P., Kanhere, S.S. \& Jha, S. 2016. Energyefficient cooperative relaying for unmanned aerial vehicles. IEEE Transactions 
on Mobile Computing, 15(6), pp.1377-1386. Available at: https://doi.org/10.1109/TMC.2015.2467381.

Milicevic, Z., \& Bakmaz, B. 2020. Drone Communications in 5G Network Environment. In: Bojkovic, S.Z., Milovanovic, A.D. \& Fowdur, P.T. (Eds.) $5 G$ Multimedia Communication:Technology, Services, and Deployment, Chapter $X$, pp.193-207. CRC Press, Taylor and Francis Group [online]. Available at: https://www.taylorfrancis.com/chapters/edit/10.1201/9781003096450-10/dronecommunications-5g-network-environment-zoran-milicevic-bojan-bakmaz [Accessed: 18.02.2019]. ISBN: 9781003096450.

Saleem, Y., Rehmani, M.H. \& Zeadally, S. 2015. Integration of cognitive radio technology with unmanned aerial vehicles: issues, opportunities, and future research challenges. Journal of Network and Computer Applications, 50, pp.15-31. Available at: https://doi.org/10.1016/j.jnca.2014.12.002.

-Wikimedia Commons. 2021a. File:Louis Charles Breguet.jpg [online]. Available at: https://commons.wikimedia.org/wiki/File:Louis_Charles_Breguet.jpg [Accessed: 15 August 2021].

-Wikimedia Commons. 2021b. File:Charles Robert Richet nobel.jpg [online]. Available

https://commons.wikimedia.org/wiki/File:Charles_Robert_Richet_nobel.jpg [Accessed: 15 August 2021].

-Wikimedia Commons. 2021c. File:Kettering-bug-1.jpeg [online]. Available at: https://commons.wikimedia.org/wiki/File:Kettering-bug-1.jpeg [Accessed: 15 August 2021].

-Wikimedia Commons. 2021d. File:Lockheed Sr-71.jpg [online]. Available at: https://commons.wikimedia.org/wiki/File:Lockheed_Sr-71.jpg [Accessed: 15 August 2021].

-Wikimedia Commons. 2021e. File:RQ-2 Pioneer on launch rail 1.JPEG [online]. Available at: https://commons.wikimedia.org/wiki/File:RQ2_Pioneer_on_launch_rail_1.JPEG [Accessed: 15 August 2021].

-Wikimedia Commons. 2021f. File:RQ-11 Raven 1.jpg [online]. Available at: https://commons.wikimedia.org/wiki/File:RQ-11_Raven_1.jpg [Accessed: 15 August 2021].

-Wikipedia. 2021. File:Archibal-Low.jpg [online]. Available at: https://en.wikipedia.org/wiki/File:Archibal-Low.jpg [Accessed: 15 August 2021].

Zeng, Y., Lyu, J. \& Zhang, R. 2018. Cellular-connected UAV: Potential, challenges, and promising technologies. IEEE Wireless Communications, 26(1), pp.120-127. Available at: https://doi.org/10.1109/MWC.2018.1800023.

Zhan, C., Zeng, Y. \& Zhang, R. 2018. Energy-efficient data collection in UAV enabled wireless sensor network. IEEE Wireless Communications Letters, 7(3), pp.328-331. https://doi.org/10.1109/LWC.2017.2776922.

Zieliński, Z., WFrona, K., Furtak, J. \& Chudzikiewicz, J. 2021. Reliability and Fault Tolerance Solutions for MloT. IEEE Communications Magazine, 59(2), pp.36-42. Available at: https://doi.org/10.1109/MCOM.001.2000940. 
ОТ СОЗДАНИЯ БЕСПИЛОТНЫХ ЛЕТАТЕЛЬНЫХ АППАРАТОВ (БПЛА) ДО ИХ ИНТЕГРАЦИИ С СЕТЯМИ БЕСПРОВОДНОЙ СВЯЗИ

Зоран М. Миличевича ${ }^{a}$ Зоран С. Бойковичб

а Вооруженные силы Республики Сербия, Генеральный штаб,

Управление телекоммуникаций и информационных технологий (J-6),

г. Белград, Республика Сербия, корреспондент,

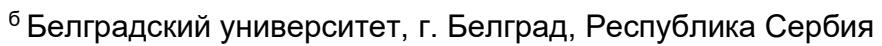

РУБРИКА ГРНТИ: 78.00.00 ВОЕННОЕ ДЕЛО:

78.25.00 Вооружение и военная техника;

78.25.31 Системы и средства военной навигации, наведения и управления,

78.25.33 Системы и средства военной связи,

49.00.00 СВЯЗЬ:

49.33.29 Сети связи

ВИД СТАТЬИ: обзорная статья

Резюме:

Введение/цель: В данной статье представлена история беспилотных летательных аппаратов (БПЛА) от их создания до интеграции в современные беспроводные сети.

Методы: Проведен анализ, синтез и сравнение развития технологий БПЛА на протяжении всей их истории, с акцентом на значимые аспекты их интеграции в сети беспроводной связи.

Результаты: B статье представлены важные аспекты беспроводной связи как одной из ключевых технологий для развития БПЛА. Также рассматривается энергоэффрективность как направление для исследований БПЛА. Помимо вышеперечисленного, в статье описано настоящее состояние БПЛА и их перспективы в будущем.

Выводы: БПЛА играют важную роль не только в различных военных операциях в боевых условиях, где они широко применяются, но они также могут быть полезны и для других целей, таких как, например, интеграция в сети $5 G$.

Ключевые слова: беспилотные летательные аппараты (БПЛА), рой дронов, военный интернет вещей.

ОД ПОСТАНКА БЕСПИЛОТНИХ ЛЕТЕЛИЦА ДО ЊИХОВЕ ИНТЕГРАЦИЈЕ У БЕЖИЧНЕ МРЕЖЕ

Зоран М. Миличевића , Зоран С. Бојковићб

а Војска Србије, Генералштаб, Управа за телекомуникације и информатику (J-6), Београд, Република Србија, аутор за преписку

б Универзитет у Београду, Београд, Република Србија 


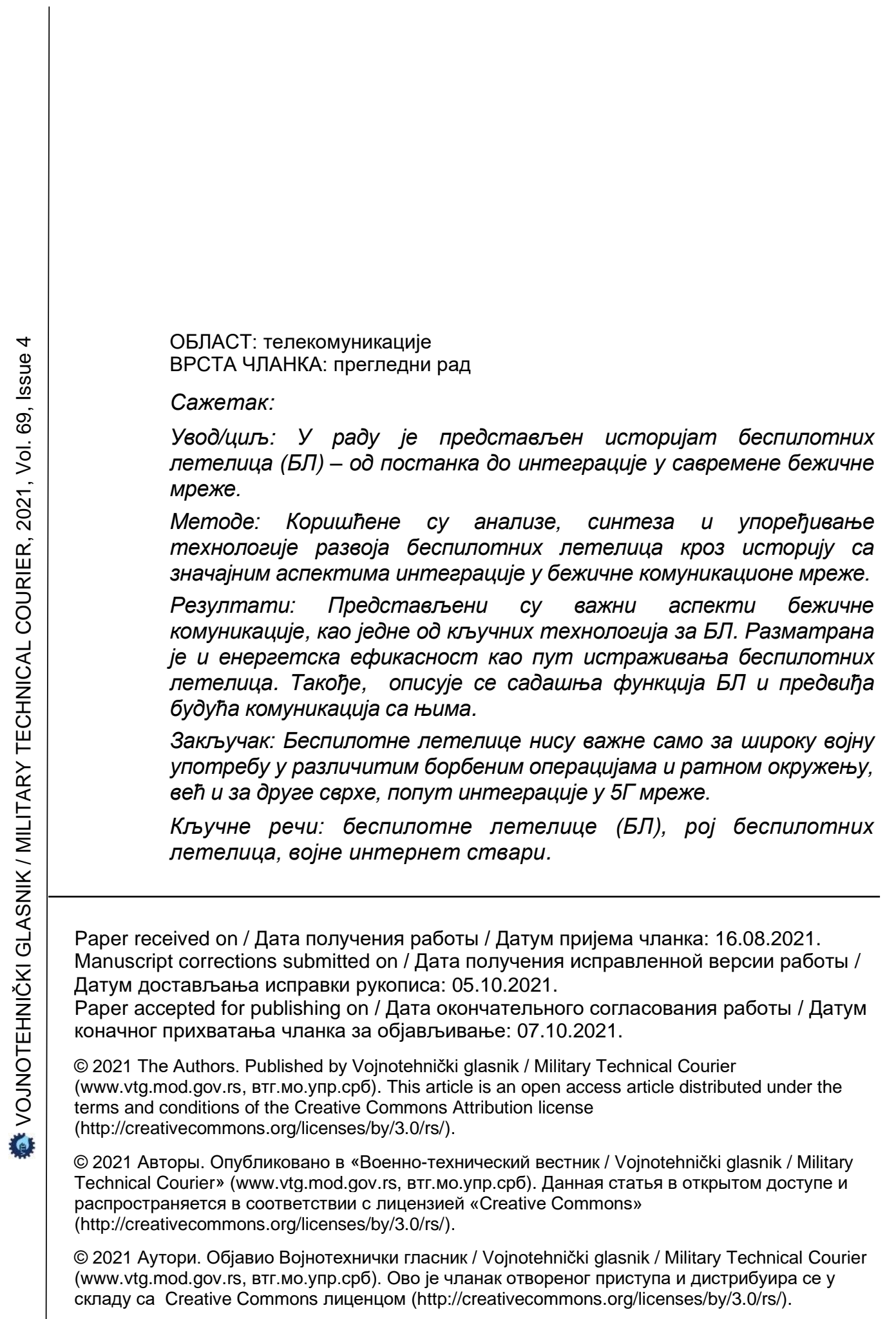
складу са Creative Commons лиценцом (http://creativecommons.org/licenses/by/3.0/rs/). 